\title{
Varroacides and their residues in bee products
}

\author{
Klaus Wallner \\ Universität Hohenheim, Landesanstalt für Bienenkunde, August-von-Hartmann-Str. 13, \\ 70593 Stuttgart, Germany
}

(Received 17 September 1998; accepted 17 February 1999)

\begin{abstract}
In general, the use of varroacides in bee colonies leaves residues in various bee products. Among the variety of available varroacides, three ingredients are commonly detectable in honey and beeswax: bromopropylate (Folbex VA Neu), coumaphos (Perizin, Asuntol) and fluvalinate (Apistan, Klartan, Mavrik). These chemicals are fat-soluble and non-volatile, and thus they accumulate in ppm levels as residues in beeswax with years of treatment. Through the process of diffusion, these ingredients migrate from the wax comb into the stored honey. In German honey, the most frequently found varroacide is coumaphos $(28 \%)$. Bromopropylate is detectable but with decreasing frequency $(11 \%)$. Because of its high binding strength in beeswax, fluvalinate detection is relatively rare in honey $(1 \%)$. All residues were found with low ppb levels. Other ingredients with similar chemical behaviour presently play an unimportant role as residues in honey, beeswax and propolis owing to the very low amount of ingredients used (acrinathrine, flumethrine) or instability (amitraz). (ㅇ) Inra/DIB/AGIB/Elsevier, Paris
\end{abstract}

Apis mellifera / varroacides / bee products / residues

\section{INTRODUCTION}

In many parts of the world, the threat of infestation by the parasitic mite, Varroa jacobsoni Oud. (Acari: Varroidae), forces beekeepers to treat their colonies with acaracides. Currently, there are many preparations and procedures available to treat the mite. The substances that can be used as treatments vary depending on their national registration. The discrepancies in the regu- lation of treatments among various countries causes much confusion, particularly among beekeepers. What beekeepers find especially frustrating is that residues from active ingredients are tolerated in imported honey in the same country where these same ingredients are prohibited for use as treatments. Since it is the purpose of these regulations to protect the users and consumers, an international standard among national regulations is needed.

E-mail: bienwa@uni-hohenheim.de 
Beekeepers and various industries benefit from the healthy and pure image that bee products present to the public. To protect this image, it is important to minimize or eliminate the residues of varroacides left behind in products in which purity and quality is expected. As food, honey must not fall short of this good image. In the cosmetic and pharmaceutical industries, beeswax is used extensively. Naturally, residues of insecticides or acaricides would not be acceptable in propolis, which is used in medicine for people in many countries.

\section{ANALYTICAL CAPABILITIES}

Inevitably, each treatment with acaracides leaves behind residues in the bee hive. Their detection depends on several factors, including the amount of active ingredient used, the chemical behaviour and, of course, the analytical capabilities in the laboratory. Many efforts have been made by scientists throughout the world to establish sensitive analytical methods for the detection of varroacides in honey and beeswax $[1,3,11$, $16,18,29,42,47,48-49,54,61,68]$. The detection limits of the varroacides in honey are low (ppb levels $<10$ ). In beeswax, they actually can be detected with levels around $0.1 \mathrm{ppm}$.
The detection of ingredients that occur naturally in honey (e.g. formic acid, lactic acid, oxalic acid, essential oils) is difficult. These substances cannot be clearly identified as a residue. When treatments are applied according to recommendations [24, 33], the detected values fall within the same range as the natural variation in honey $[12,31,36$, $39,45,46,57]$. Therefore, a regular check of the residue level is not required. For these reasons, beekeepers would find these ingredients to be very suitable as varroacides. On the other hand, residues of synthetic insecticides or acaricides can be clearly identified, and as they are foreign substances in honey they have to be evaluated toxicologically. Independent of the residue values, these synthetics generally damage the image of honey and other bee products.

\section{AMOUNT OF THE ACTIVE INGREDIENT}

When impregnated carriers are inserted into the hive, the amounts of active ingredients in the strips can vary enormously among different formulations (table I). The precise amount of substance that is released per unit of time is unknown and may differ between treatments. The analysis of Apistan strips before and after use in colonies confirmed that only a fraction of the active

Table I. Active ingredient in different carriers and drip solutions.

\begin{tabular}{lcc}
\hline Carrier & Active ingredient & Substance per strip \\
\hline Apistan & fluvalinate & $800 \mathrm{mg}$ \\
Apivar & amitraz & $500 \mathrm{mg}$ \\
Bayvarol & flumethrine & $3.6 \mathrm{mg}$ \\
Gabon PA & acrinathrine & $1.5 \mathrm{mg}$ \\
Drip solution* & Active ingredient & Substance of two applications \\
\hline Apitol & cymiazole & $260 \mathrm{mg}$ \\
Perizin & coumaphos & $64 \mathrm{mg}$ \\
Klartan/Mavrik $0.01 \%$ & fluvalinate & $2.4 \mathrm{mg}$ \\
\hline
\end{tabular}

\footnotetext{
* Dosage: $50 \mathrm{~mL}$ suspension per colony on each application.
} 
ingredient in the strips would be sufficient for treatment [22]. The amount of substance finally distributed throughout the colony depends on the amount of active ingredient impregnated in the strip, on the activity of the bees and on the duration of the application. The more of the active ingredient a strip contains and the longer it is in contact with bees, the greater is the distribution of the ingredient within the colony and the higher the risk of measurable residues. Carriers with small amounts of active ingredient do not leave measurable residues in beeswax, even with excessively long applications. For this reason, residues of fluvalinate (Apistan) in wax can be found very often $[14,17,40,67]$ but residues of flumethrine (Bayvarol) or acrinathrine (Gabon PA) are found only rarely $[5,55,64]$.

Acaricides which are used with similar efficacy as drip solutions (liquid formations that are dripped directly onto the bees) bring different amounts of ingredient into the bee hive [32]. Table I shows the amounts used of some more widely used acaricides, such as
Apitol, Perizin and Klartan or Mavrik $(0.01 \%)$. When the amount of ingredient increases, the risk of measurable residues also increases. Treatments with Apitol regularly create residues in honey at levels of around $100 \mathrm{ppb}$. When Klartan/Mavrik suspensions are used, detectable residues are very rare [59].

\section{CHEMICAL BEHAVIOUR}

The active ingredients of varroacides can be divided by into two main groups: the water-soluble (hydrophilic) and the fat-soluble (lipophilic) ingredients (table II).

\subsection{Water-soluble chemicals}

Water-soluble, active ingredients such as formic acid [45, 46], oxalic acid [39] and cymiazole $[19,60]$ endanger the quality of honey since these substances are diluted easily in honey. The use of these substances during the nectar flow always results in con-

Table II. The chemical character of some varroacides.

\begin{tabular}{|c|c|c|c|}
\hline & Volatile or unstable & Non-volatile & Active ingredient of \\
\hline Fat/Wax soluble & $\begin{array}{c}\text { amitraz } \\
\text { thymol* } \\
\text { majoram oil } \\
\text { wintergreen oil }\end{array}$ & $\begin{array}{l}\text { acrinathrine } \\
\text { bromopropylate } \\
\text { coumaphos } \\
\text { chlorfenvinphos } \\
\text { chlordimeform } \\
\text { fluvalinate } \\
\text { flumethrine } \\
\text { tetradifon }\end{array}$ & $\begin{array}{c}\text { Gabon PA } \\
\text { Folbex VA Neu } \\
\text { Perizin/Asuntol } \\
\text { Birlane } \\
\text { Galecron/K79 } \\
\text { Apistan/Klartan/Mavrik } \\
\text { Bayvarol } \\
\text { Tedion } \\
\text { Apivar, Antivarroa } \\
\text { Api Life VAR } \\
- \\
-\end{array}$ \\
\hline \multirow[t]{2}{*}{ Water soluble } & formic acid* & & - \\
\hline & & $\begin{array}{l}\text { lactic acid* } \\
\text { oxalic acid* } \\
\text { cymiazole }\end{array}$ & $\begin{array}{c}- \\
- \\
\text { Apitol }\end{array}$ \\
\hline
\end{tabular}

\footnotetext{
* Substance can be found naturally in honey.
} 
siderable residues. Organic acids may also impart a false taste to the honey. The honey harvest or consumption of honey by bees in the colony reduces the available amount of substance in the hive. However, volatile residues such as formic acid decrease in stored food and extracted honey over time $[12,45]$. Water-soluble ingredients have no negative long-term effect on beeswax quality since they are not stored in beeswax. Therefore, an accumulation of such substances in the wax does not occur.

\subsection{Fat-soluble, stable, active ingredients}

The situation is different in the case of fat-soluble substances. First of all, these ingredients are stable and increase in the wax comb. From the wax, they migrate into the stored honey. Laboratory samples given the same conditions as in the bee colony showed this migration clearly [58]. The higher the concentration in the wax, the more residues that could be detected in the honey. Another negative effect is the contamination of wax particles in the honey [63]. Contaminated wax is a significant source of residues in honey because a natural degradation of varroacides in beeswax does not occur. Rather, there is an accumulation due to repeated applications. The capacity of beeswax is enormous and the recycling of old combwax into foundations does not change the content of the active ingredient [5]. Also, the technical capabilities for cleaning of wax are limited [56, 63]. Only the complete destruction of beeswax, by burning the wax as a candle for example, can destroy the stored ingredients [66]. Therefore, residues are detectable and the quality of the wax is permanently damaged in beeswax from all countries where these substances are used. In summary, fat-soluble ingredients, especially when they are stable and non-volatile, represent a great risk in apiculture of long-term residue accumulation.

\subsection{Fat-soluble, volatile or unstable active ingredients}

Within the group of fat-soluble active ingredients, there are varroacides whose concentration can decrease in beeswax. This decrease is because they contain semivolatile ingredients such as essential oils (e.g. thymol, wintergreen oil), and other substances, which can decay into metabolites (e.g. amitraz). During the application of the treatment, only some of the semi-volatile ingredients attach to the wax, while a majority evaporates because of the temperature of the hive [25]. As a result, the amount actually left in the wax is effectively reduced. Although, an accumulation of residue does not occur during the years of application, traces remain detectable in honeycomb [6]. The amount of the ingredient can also be effectively reduced during the recycling of old wax into foundations, if the wax is not only liquefied but also steamed.

\subsection{Amitraz is metabolized}

A well-known representative of unstable, fat-soluble varroacides is amitraz, which has been used in several countries for many years. Amitraz is not stable in honey, and so almost completely degrades into several decomposed metabolites after 3-4 weeks $[3,27]$. Therefore, all efforts to detect amitraz residues in honey have been unsuccessful [3, 10, 18, 34]. Amitraz also does not remain stable in beeswax. Conversely, beeswax seems to have an accelerating effect on the degradation of amitraz. Experiments with amitraz and bromopropylate on plates of aluminium foil and beeswax showed that amitraz on beeswax disappears within hours. Both ingredients were dissolved in acetone-hexane (1:1) with a concentration of $1 \mathrm{ng} \cdot \mu \mathrm{L}^{-1}$. A series of thin beeswax and aluminium plates were stamped out and $5 \mu \mathrm{L}$ of the solution were delivered through pipettes onto each plate. After a certain time, the plates were placed with $1 \mathrm{~mL}$ 
acetone-hexane into vials with seals. The beeswax plates dissolved completely after shaking the vial. The analysis of the solution and the calculation were performed with a Shimadzu GC-MS QP 5050 system.

Figure $l$ shows the rapid breakdown of amitraz on the beeswax plates. The active ingredient decays with room temperature into known metabolites, mainly into the poisonous, volatile 2.4 dimethyl-aniline. As expected, the substance, bromopropylate, remained stable on both materials. Higher temperatures, which are common in foundation production, accelerate this degradation significantly. Therefore, an increase in amitraz in beeswax during the years of application can be excluded. Amitraz remains stable for months within other materials, such as aluminium foil or organic solvents.

\section{DISTRIBUTION OF}

VARROACIDES IN THE BEEHIVE

Fat-soluble ingredients are distributed throughout the colony by the bees' legs and bodies. All inner surfaces of the hive that are walked on by bees, such as the frames, bottoms and covers, are coated with a very thin layer of wax. Lipophilic substances are stored there and may pass in measurable amounts into other bee products such as virgin wax and propolis. Therefore, it is not important in which form the substance was initially inserted into the bee hive. Smoke strips (Folbex VA Neu, Amitraz), or other diffusers, distribute the ingredient during application, covering the entire interior of the bee hive with a fine film composed of the substance. This includes open brood, stored pollen and uncapped nectar.

By using carriers, the active ingredient is only inserted into limited areas of the hive. Within a short time, the bees distribute this substance throughout the whole hive [67]. This very rapid distribution was discovered using radioactive marked wax [13] and confirmed with combs from fluvalinate- or flumethrine-treated colonies, which retained a varroacide effect in untreated colonies [9, 38]. Experiments with swarms from untreated colonies, which were placed in used hive bodies without foundation, showed measurable amounts of bromopropylate in the comb wax after a few weeks [8].

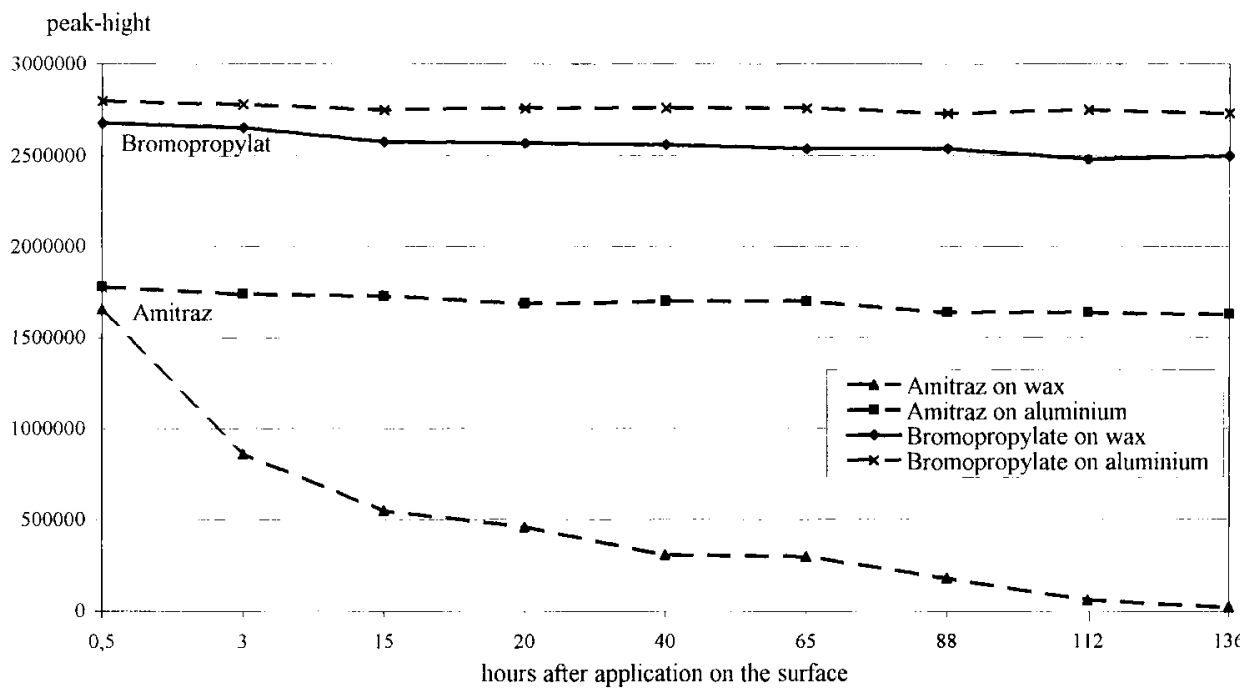

Figure 1. Stability of amitraz and bromopropylate on aluminium foil and on beeswax. 
Fat-soluble treatments such as coumaphos or fluvalinate can be detected in stored or extracted honey when beekeepers use drip solutions. The risk of residue accumulation is correlated with the amount of the ingredient used and the number of applications during the year. Drops of the suspension unavoidably land in open cells and contaminate the cell contents directly. Only $24 \%$ of an applied coumaphos drip solution were found to reach the alimentary canal of bees, the rest of the solution remained in other places in the bee hive [52]. Furthermore, another method of residue accumulation has been observed during bee intoxication caused by plant-protective agents. When bees make contact with poisonous substances, they react by significantly increasing their food intake [62], which decreases the concentration of the active substance in the honey sac and thus weakens the poisonous effect. After a certain time, the bees regurgitate a portion of the contaminated food into the cells, causing the remaining cell contents and the cell walls to come into contact with the treatment.

Bees which mature and live in contaminated hives contain varroacides in the fat tissue of their bodies and on the surface of their bodies [65]. Swarms that originate from coumaphos-treated colonies with levels of coumaphos around $15 \mathrm{mg} \cdot \mathrm{kg}^{-1}$ in the wax secrete virgin wax that has residues with levels of more than $1 \mathrm{mg} \cdot \mathrm{kg}^{-1}$. Similar results were shown from experiments with colonies that produced contaminated wax 6-18 months after the last treatment with coumaphos [53].

\section{RESIDUES IN HONEY}

Honey analysis in different laboratories showed that, with few exceptions, residues of the stable, lipophilic treatments can be found. Up to now, the following varroacides have been detected with ppb levels in honey: bromopropylate $[7,23,29,44,57,59]$, coumaphos $[15,21,29,50,57,59]$, fluvalinate $[7,14,59]$, malathion $[2,50]$, diazinon
[21], chlordimeform [28] and cymiazole [19].

Since 1988, long-term studies have been carried out at the University of StuttgartHohenheim, in which up to 1000 honey samples are analysed per year within the scope for general quality control. In German honey, residues of three synthetic varroacides are detectable. They all belong to the group of non-volatile, fat-soluble substances.

\subsection{Bromopropylate (Folbex VA Neu)}

Although this ingredient has not been used in Germany for 8 years, in approximately $11 \%$ of German honey bromopropylate residues can be found in amounts of 2-10 ppb. In 1996, the percentage of positive samples was $17.4 \%$, and in 1995 was $20.2 \%$. Without exception, these residues come from accumulation of the active ingredient in wax combs, on frames and hive walls, and from foundation made from contaminated wax. Ever since the high residue risk of this treatment was recognized, German beekeepers voluntarily discontinued its use. However, Folbex VA Neu is still registered. In the past, residues of bromopropylate were detected in honey with levels above $100 \mathrm{ppb}$.

\subsection{Coumaphos (Perizin/Asuntol)}

Today, Perizin is the most frequently used drip solution in German apiaries. It is mainly used during the wintertime in colonies without brood, but sometimes it is also used in late summer in multiple treatments in colonies with brood. Coumaphos represents the most frequently detectable varroacide in honey. In 1997, approximately $28 \%$ of examined honey were contaminated with levels between 2 and 15 ppb. Similar residue levels were found in 1995 and 1996 in 24.5 and $31 \%$ of the analysed samples, respectively. 


\subsection{Fluvalinate (Klartan/Mavrik/Apistan)}

Fluvalinate belongs to the group of synthetic pyrethroids. It is used for control of $V$. jacobsoni worldwide $[35,51]$. Impregnated carriers are inserted into the colony with amounts of fluvalinate in grams. In drip solutions, the necessary amount of ingredient is extremely low in comparison to other systemic varroacides (coumaphos, cymiazole) (table I). Residues in German honey are found only rarely when mistakes occur in the application and/or in the preparation of the drip solution, and if residues in the wax are at a high level after several years of application. In these instances, the substance migrates by diffusion from the comb into the honey. Fluvalinate can be found in $1 \%$ of honey produced in Germany with residue levels between 2 and $7 \mathrm{ppb}$. Higher amounts reaching $40 \mathrm{ppb}$ were found in honey from eastern Europe, and are also reported from other countries [30]. Recently, fluvalinate-resistant mites have appeared in several countries, which indicate that the continued use of the whole group of synthetic pyrethroids is questionable $[37,51]$. The remaining synthetic var- roacides play a subordinate role in residues in German honey.

There are few publications on the stability of residues in honey. In laboratory tests with spiked honeys, a reduction of over $90 \%$ of coumaphos and malathion residues was found after storage for 3 months [50]. In the case of fluvalinate, similar observations were made, as well as the observation that these substances degrade into several metabolites [26]. Nevertheless, there is no confirmation of this described rapid instability of coumaphos and fluvalinate in honey in the long-term studies at Stuttgart-Hohenheim.

\subsection{National regulations}

For consumer protection, the acceptable residue levels in honey are determined nationally (MRL: maximum residue levels) and influence the procedures for checking food in individual countries. National regulations are not homogeneous (table III) which causes problems in the international marketing and trade of honey. Generally, the permitted residue levels of synthetic varroacides in honey are very low; although

Table III. Official limits of varroacide residues $\left(\mu \mathrm{g} \cdot \mathrm{kg}^{-1}\right)$ in honey (from Piro [41]).

\begin{tabular}{lcccccc}
\hline & Italy & Netherlands & Germany & Switzerland & EU & USA \\
\hline Coumaphos & $10^{*}$ & $50^{\#}$ & 10 & 50 & n.c. & n.c. \\
Amitraz & $10^{*}$ & $20^{\#}$ & $10^{*}$ & 10 & 200 & 1000 \\
Fluvalinate & $10^{*}$ & $50^{\#}$ & $10^{*}$ & 50 & n.c. & 50 \\
Flumethrine & $10^{*}$ & n.c. & $10^{*}$ & 5 & no MRL & n.c. \\
Cymiazole & $10^{*}$ & 500 & $10^{*}$ & 500 & 1000 & n.c. \\
Bromopropylate & $10^{*}$ & $50^{\#}$ & $100^{*}$ & 100 & n.c. & n.c. \\
Tetradifon & $10^{*}$ & $0^{\#}$ & $10^{*}$ & n.c. & n.c. & n.c. \\
Chlordimeform & $10^{*}$ & $0^{\#}$ & 10 & n.c. & n.c. & n.c. \\
Thymol & n.c. & n.c. & n.c. & 800 & no MRL & n.c. \\
Lactic acid & n.c. & n.c. & n.c. & 40 meq.kg $\mathrm{kg}^{-1}$ & no MRL & n.c. \\
Oxalic acid & n.c. & n.c. & n.c. & $40 \mathrm{meq} \cdot \mathrm{kg}^{-1}$ & n.c. & n.c. \\
Formic acid & n.c. & n.c. & n.c. & $40 \mathrm{meq} \cdot \mathrm{kg}^{-1}$ & no MRL & n.c. \\
\hline
\end{tabular}

* Generic limit; ${ }^{\#}$ zero tolerance (= detection limits of analytical method). n.c.: not considered; no MRL: limit is not necessary. 
honey consumption is considerably lower than other foods, in which higher levels are tolerated (e.g. meat and vegetables). Harmonization of these permitted levels is being planned currently among European countries and perhaps others as well [41].

\section{RESIDUES IN WAX}

Most of the fat-soluble substances, with the exception of amitraz, are widely used as varroacides and can be found with ppm levels in beeswax. Up to now, the following varroacides have been detected in wax: bromopropylate $[4,23,44,57,67,64]$, coumaphos $[15,53,57,64,67,68]$, fluvalinate $[7$, $14,17,30,34,43,64]$, flumethrine [5] and tetradifon [64].

Because of the very small amount of substance used, levels of acrinathrine and flumethrine in beeswax from apiaries can be expected to be below the detection limit of most laboratories. Since 1993, 300-400 beeswax samples have been analysed per year at the University of Hohenheim. Most of these samples were received directly from beekeepers.

\subsection{The current situation}

The situation is not homogeneous, since beekeepers' concepts of treatments can vary greatly. The active ingredients listed in the above paragraph are detectable in beeswax and as residues in honey. The measured values of bromopropylate, coumaphos and fluvalinate are in the ppm area (detection limits $0.5 \mathrm{mg} \cdot \mathrm{kg}^{-1}$ ). More than $90 \%$ of the examined local samples are contaminated. Often several of these varroacides can be found in the same sample. However, there is an increasing number of beekeepers who have stopped using fat-soluble ingredients and use organic acids exclusively. No residues can be found in the wax of these apiaries, provided that residue-free foundation is used.

Table IV shows summarized results of the wax analyses for the year 1997 with a comparison of the situation in national and international apiaries. As expected, German wax is contaminated with high percentages of bromopropylate $(54.9 \%)$ and coumaphos $(61.0 \%)$. A large number of samples contains amounts between 1 and $5 \mathrm{ppm}$. On the other hand, more than half of the international samples $(55.0 \%)$ are contaminated

Table IV. Varroacides in bees wax from apiaries. Situation in German $(n=226)$ and international samples $(n=158)$. Percentage of positive samples in the different contamination ranges (1997).

\begin{tabular}{|c|c|c|c|c|c|c|}
\hline \multirow{3}{*}{$\begin{array}{l}\text { Varroacide } \\
\text { Ingredient } \\
\left(\mathrm{mg} \cdot \mathrm{kg}^{-1}\right)\end{array}$} & \multicolumn{2}{|c|}{$\begin{array}{l}\text { Folbex Va } \\
\text { Neu }\end{array}$} & \multicolumn{2}{|c|}{$\begin{array}{l}\text { Perizin/ } \\
\text { Asuntol }\end{array}$} & \multicolumn{2}{|c|}{$\begin{array}{c}\text { Apistan/Klartan } \\
\text { Mavrik }\end{array}$} \\
\hline & \multicolumn{2}{|c|}{ Bromopropylate } & \multicolumn{2}{|c|}{ Coumaphos } & \multicolumn{2}{|c|}{ Fluvalinate } \\
\hline & German & International & German & International & German & International \\
\hline $0.5-1$ & 17.2 & 7 & 18.6 & 8.9 & 13.3 & 13.3 \\
\hline$>1-5$ & 28.3 & 13.3 & 36.3 & 7 & 23 & 36.1 \\
\hline$>5-10$ & 7.5 & 0.6 & 5.3 & 1.9 & 0.9 & 3.8 \\
\hline$>10-15$ & 1.8 & 0 & 0.4 & 0.6 & 0 & 1.9 \\
\hline$>15-20$ & 0 & 0 & 0 & 0.6 & 0 & 0 \\
\hline$>20-25$ & 0 & 0 & 0.4 & 0 & 0 & 0 \\
\hline$>25$ ppm & 0 & 0 & 0 & 0 & 0 & 0 \\
\hline $\operatorname{sum}(\%)$ & 54.9 & 20.9 & 61 & 19 & 37.2 & 55.1 \\
\hline
\end{tabular}


with fluvalinate. This active substance can also be found with increasing frequency in German wax. In 1996, the percentage of positive samples was $23.6 \%$ and in 1995 only $13.2 \%$. Similar frequencies with slightly higher levels were shown in other countries $[7,14,34,40]$. As a fat-soluble, non-volatile substance, fluvalinate plays the chief role as a residue-creating substance in beeswax.

The same frequencies are also found in wax foundation on the national and foreign market, as beeswax is an internationally traded product. Additional ingredients, which are unknown as varroacides in Germany (e.g. tetradifon), reach the apiaries via foundation produced from imported wax. A clear difference can be seen in the comparison of foundation produced from German or foreign wax. As expected, residues of bromopropylate $\left(0.5-10 \mathrm{mg} \cdot \mathrm{kg}^{-1}\right)$ and coumaphos $\left(0.5-3.5 \mathrm{mg} \cdot \mathrm{kg}^{-1}\right)$ can be found in a high percentage (both $62.5 \%$ ) in foundation from wax produced in Germany. These ingredients are rarely found in imported wax $(1.7 \%)$ and are rare in foundation from foreign countries ( 1 and $20 \%$, respectively). In foreign foundation, fluvalinate is quite often detectable with similar residue values in the range $0.5-3.5 \mathrm{mg} \cdot \mathrm{kg}^{-1}$. Within 26 examined samples, five were free of measurable varroacides. These samples came from New Zealand, Denmark, Uruguay and Africa.

In general, residues of varroacides in beeswax are not regulated. With the exception of the USA (fluvalinate: $6 \mathrm{ppm}$ ), no official limits exist. Since great amounts of beeswax are processed for pharmaceutical purposes or for the food and cosmetics industries, pesticide residues are problematic. Several companies have created their own internal maximum limits to which contaminated beeswax is acceptable. Because of the easy migration of substances into honey, comb wax should have the least amount of contamination. To ensure that there is no measurable effect, residues in the wax should be lower than $1 \mathrm{mg} \cdot \mathrm{kg}^{-1}$ [63].

\subsection{Biological effects of residues in beeswax}

The effect on mortality and fertility of Varroa jacobsoni caused by acaricide residues in beeswax was investigated [20]. Field experiments with coumaphos- and fluvalinate-impregnated foundations $(0,1,10$, $100 \mathrm{ppm}$ ) showed that there is a measurable effect on the survival of mother mites, depending on the type and concentration of the acaricide. Coumaphos levels of over $10 \mathrm{ppm}$ in the wax comb killed a high percentage of mites that went into the cells for reproduction. Fluvalinate showed these effects, but only in unrealistically high levels of around $100 \mathrm{ppm}$ in the wax. When the cell walls were covered with cocoons, both substances lost the described effect in any of the tested concentrations. Obviously, the honeybee cocoon is an effective barrier that prevents mites from entering the sealed cells. No negative effects on the bees or the brood were observed during this experiment [20].

\section{RESIDUES IN PROPOLIS}

Few data exist on the influence of varroacides on the quality of propolis. Propolis that is mainly used in apitherapy should be free of measurable pesticides. The available data show that propolis has a high affinity to fat-soluble varroacides and is susceptible to contamination. For example, bromopropylate was detected with levels $>11 \mathrm{ppm}$ after fumigation [44] and fluvalinate had levels $>8 \mathrm{ppm}[30]$, in single samples of more than $50 \mathrm{ppm}[63]$ after using Apistan strips. Alcoholic extractions of contaminated rough material also contained residues, independent of the alcohol concentration (50-98\%).

\section{CONCLUSION}

The treatment of colonies against $V$. jacobsoni influences the quality of bee products in many countries of the world. 
Depending on the chosen varroacide, a varying level of residues can be found in honey, beeswax and propolis. Discussions on the toxicology of these residues are endless, as the current official limits do not contribute to an objective consideration of the topic. In the future management of honeybees, it is important to consider that as soon as there is a choice between contaminated and residuefree products, consumers will choose the latter.

The use of synthetic, lipophilic varroacides in colonies should be minimized, and the use of organic acids or essential oils increased. It is also necessary to change habits of recycling wax into foundation. Old combs that are contaminated should not be used for the production of foundation. Instead, foundation should be made from virgin wax and wax cappings. With an increased production of virgin wax in colonies, a system to separate out contaminated combs from the wax recycling process, and an efficient acaracide application system, residue levels in bee products can be maintained below the detectable limits and far below the maximum residue levels.

\section{Résumé - Les varroacides et leurs rési- dus dans les produits du rucher. Les trai-} tements contre l'acarien Varroa jacobsoni pèsent actuellement sur la qualité des produits du rucher dans de nombreux pays. La discussion sur le caractère dangereux des résidus porte atteinte à l'image positive qu'a le public de ces produits. Les désaccords entre pays concernant la réglementation des produits de traitement autorisés et les limites maximales admissibles (tableau III) ne contribuent pas à dépassionner le débat.

La nature chimique du varroacide et la quantité de substance appliquée peuvent énormément varier (tableaux $I$ et $I I$ ). Les substances hydrosolubles (acides formique, lactique, oxalique) sont dangereuses pour la qualité du miel, puisqu'elles peuvent être diluées dans le miel. La cire accumule et stabilise les substances liposolubles qui peu- vent ensuite migrer des rayons de cire dans le miel entreposé ou le polluer sous forme de particules de cire.

À quelques rares exceptions les varroacides lipophiles utilisés ont pu être retrouvés dans le miel également (limite de détection $<10 \mathrm{ppb}$ ). Des données existent actuellement pour les matières actives (m.a.) suivantes : bromopropylate, coumaphos, fluvalinate, malathion, diazinon, chlordimeform et cymiazole.

À l'heure actuelle des résidus de trois m.a. non volatiles et liposolubles sont principalement présents daans les miels allemands. Dans près de $11 \%$ des miels allemands on trouve des résidus de bromopropylate (Folbex VA Neu) dans les limites de 2-10 ppb ; ils provenaient tous sans exception de la m.a. qui s'était fixée dans les rayons à la suite de traitements effectués les années passées. Le coumaphos (Perizin) fournit les résidus les plus souvent détectés dans le miel. Environ $28 \%$ de tous les miels allemands en contenaient des résidus, de l'ordre de 2-15 ppb. On trouve des valeurs semblables dans les miels étrangers. En comparaison le fluvalinate (Klartan, Mavrik, Apistan) apparaît rarement dans le miel. Environ $1 \%$ des miels allemands présentent des résidus de fluvalinate et ce dans des limites plus basses (2-7 ppb). Des quantités de m.a. allant jusqu'à 40 ppb ont été retrouvées dans des échantillons provenant d'Europe de l'Est. Les résidus d'amitraz sont instables dans le miel. L'amitraz se décompose presque totalement en trois à quatre semaines en produits de dégradation. Dans la cire non plus la m.a. présente à l'origine n'est pas stable (figure 1).

Dans aucun autre pays à l'exception des États-Unis (fluvalinate : $6 \mathrm{ppm}$ ), il n'existe de limites supérieures fixées pour les résidus de varroacides dans la cire. Si l'on compare la situation de l'apiculture en 1997 en Allemagne et dans les pays étrangers, il est évident que l'on trouve des pourcentages plus élevés de bromopropylate $(54,9 \%)$ et de coumaphos $(61,0 \%)$ dans les miels allemands. La majorité des échantillons ren- 
ferme des quantités de m.a. comprises entre 1 et $5 \mathrm{ppm}$. En revanche plus de la moitié des échantillons étrangers $(55,0 \%)$ sont pollués par le fluvalinate. La tendance à retrouver cette m.a. dans les miells allemands augmente : en 1996, 23,6\% des échantillons étaient positifs contre seulement $13,2 \%$ en 1995 ( ableau IV). Le commerce international de la cire fait apparaître d'autres m.a. inconnnues en Allemagne comme varroacides (par exemple, le tétradifon). Sur les 26 cires gaufrées étudiées en 1997, seules cinq échantillons, provenant de NouvelleZélande, du Danemark, de Finlande, d'Uruguay et d'Afrique, étaient dépourvus de résidus quantifiables de varroacides.

On ne dispose jusqu'à présent que de peu de données concernant les résidus de varroacides dans la propolis. On a mis en évidence, parfois en quantités élevées, la présence de résidus de bromopropylate ( $>11 \mathrm{ppm}$ ) et de fluvalinate (> $50 \mathrm{ppm}$ ).

Pour abaisser le pourcentage d'échantillons de miel, de cire et de propolis pollués, il faut inclure les acides organiques et les huiles essentielles dans les méthodes de lutte. L'utilisation de varroacides liposolubles doit être minimisée et la production de cire vierge accrue. La vieille cire polluée doit être retirée du circuit de la cire gaufrée. (C) Inra/DIB/ AGIB/Elsevier, Paris

\section{Apis mellifera / Varroa jacobsoni / acaricide / produits du rucher / résidu}

\section{Zusammenfassung - Varroabekämp- fungsmittel und ihre Rückstände in Bie-} nenprodukten. Die Bekämpfung der Varroamilbe beeinflußt derzeit die Qualität der Bienenprodukte in vielen Ländern. Die Diskussion über die Gefährlichkeit von Rückständen schadet dem Ansehen der Bienenprodukte in der Öffentlichkeit. Die Unstimmigkeiten zwischen den Ländern bei der Regelung der zugelassenen Bekämpfungsmittel und den zulässigen Höchstgrenzen (Tabelle $I I I)$ sind für eine Ver- sachlichung dieser Diskussion nicht geeignet.

Der chemische Charakter der Varroazide und ihre applizierten Substanzmengen können sehr unterschiedlich sein. (Tabelle I und $I$ ). Wasserlösliche Wirkstoffe (Ameisensäure, Milchsäure, Oxalsäure) gefährden die Honigqualität, da diese Substanzen von Honig leicht aufgenommen werden. Fettlösliche Substanzen werden im Wachs gespeichert und stabilisiert. Aus dem Wabenwachs können sie in den eingelagerten Honig einwandern oder in Form von Wachspartikeln zu belastetem Honig führen.

Mit nur wenigen Ausnahmen werden die angewandten lipophilen Varroazide auch im Honig nachgewiesen (Nachweisgrenzen $<10 \mathrm{ppb}$ ). Daten liegen zu folgenden Wirkstoffen vor: Brompropylat, Coumaphos, Fluvalinat, Malathion, Diazinon, Chlordimeform und Cymiazol.

In deutschen Honigen treten derzeit hauptsächlich Rückstände von drei nichtflüchtigen, fettlöslichen Wirkstoffen auf: In ca. $11 \%$ der deutschen Honige können im Bereich von 2-10 ppb Brompropylat-Rückstände gefunden werden. Diese Rückstände stammen ausnahmslos aus dem Wirkstoffdepot, das in den zurïckliegenden Anwendungsjahren im Wabenwachs angelegt wurde.

Coumaphos (Perizin) stellt den am häufigsten nachweisbaren Rückstand im Honig dar. Etwa $28 \%$ aller untersuchten einheimischen Honige enthalten Rückstände in Größenordnungen von 2-15 ppb. Mit ähnlichen Rückstandswerten wird Coumaphos auch in Auslandsproben gefunden.

Fluvalinat (Klartan/Mavrik/Apistan) taucht im Honig vergleichsweise selten auf. Etwa $1 \%$ der einheimischen Honige weisen Rückstände im unteren ppb-Bereich (2-7 ppb) auf. Höhere Wirkstoffmengen bis $40 \mathrm{ppb}$ wurden in Proben aus Osteuropa nachgewiesen.

Amitraz-Rückstände sind im Honig nicht stabil. Amitraz zerfällt nach 3-4 Wochen nahezu vollständig in verschiedene Abbauprodukte. Auch im Bienenwachs bleibt der 
ursprünglich eingesetzte Wirkstoff nicht stabil $(A b b . l)$.

Für Rückstände von Varroabekämpfungsmitteln im Bienenwachs gibt es, mit Ausnahme der USA (Fluvalinat 6 ppm) in keinem Land festgelegte Höchstgrenzen.

Stellt man die Situation (1997) in den Imkereien im In- und Ausland gegenüber, wird deutlich, da $\beta$ in hohen Prozentsätzen in deutschem Wachs die Wirkstoffe Brompropylat $(54,9 \%)$ und Coumaphos $(61,0 \%) \mathrm{zu}$ finden sind. Die überwiegende Zahl der Proben enthält Wirkstoffmengen zwischen 1 und $5 \mathrm{ppm}$. Dagegen ist mehr als die Hälfte der Auslandsproben $(55,0 \%)$ mit Fluvalinat belastet. In deutschen Proben kann dieser Wirkstoff mit zunehmender Tendenz gefunden werden. 1996 betrug die Zahl der positiven Proben 23,6\% und 1995 lediglich $13,2 \%$.

Über den internationalen Wachshandel tauchen zusätzliche Wirkstoffe auf, die in Deutschland als Varroazide unbekannt sind (z.B. Tetradifon). Von den insgesamt $26 \mathrm{im}$ Jahr 1997 untersuchten internationalen Mittelwandchargen waren lediglich 5 frei von meßbaren Varroazidrückständen. Das Wachs dieser Chargen kam aus Neuseeland, Dänemark, Finnland, Uruguay und Afrika. Bisher liegen nur wenige Daten zur Rückstandssituation von Varroaziden in Propolis vor. Nachgewiesen wurden Brompropylat (>11 ppm) und Fluvalinat mit teilweise sehr hohen Rückstandsmengen (>50 ppm).

Um den Anteil der meßbar belasteten Honig-, Wachs- und Propolisproben zu senken, müssen zukünftig vor allem die organischen Säuren in die Bekämpfungskonzepte aufgenommen werden. Auf der anderen Seite mu $\beta$ der Einsatz von fettlöslichen Medikamenten optimiert und die Produktion von Jungfernwachs gesteigert werden. Kontaminiertes Altwachs mu $\beta$ aus dem Kreislauf über Mittelwände herausgenommen werden. (C) Inra/DIB/AGIB/Elsevier, Paris

\section{Apis mellifera / Varroabekämpfungsmittel / Bienenprodukte / Rückstände}

\section{REFERENCES}

(1) Atienza J., Jimenez J., Bernal J.L., Martin M.T., Supercritical fluid extraction of fluvalinate residues in honey. Determination by high-performance liquid chromatography, J. Chromatogr. 655 (1993) 95-99.

[2] Balayannis P.G., Santas L.A., Dissipation of malathion and fluvalinate residues from honey, J. Apic. Res. 31 (1992) 70-76.

[3] Bogdanov S., Bestimmung von Amitraz und seinen Metaboliten in Honig durch HPLC, Mitteilung der Sektion Bienen 3 (1988) 1-9.

[4] Bogdanov S., Kilchenmann V., Acaricide residues in beeswax: long-term studies in Switzerland, Apidologie 26 (1995) 319-321.

[5] Bogdanov S., Kilchenmann V., Imdorf A., Acaricide residues in beeswax and honey, in: Mizrahi A., Lensky Y. (Eds.), Bee Products, Plenum Press, New York, 1997, pp. 239-246

[6] Bogdanov S., Imdorf A., Kilchenmann V., Residues in wax and honey after Api Life VAR treatment, Apidologie 29 (1998) 513-524.

[7] Bogdanov S., Kilchenmann V., Imdorf A., Acaricide residues in some bee products, J. Apic. Res. 37 (1998) 57-67.

[8] Büchler R., Erzeugung von Naturbau und mögliche Auswirkungen auf die Volksentwicklung, Allg. Dtsch. Imkerztg. 30 (1996) 20-23.

[9] Büchler R., Maul V., The after-effect of Bayvarol treatment in honey bee colonies on varroa mites introduced later on, Apidologie 22 (1991) 389-396.

[10] Bussiéras J., Goetz C., Weissenberger J., Essai de traitement au moyen d'amitraz sur support solide, Rev. Fr. Apic. 470 (1988) 23-26.

[11] Cabras P., Determination of cymiazole residues in honey by liquid chromatograpy, J. Assoc. Off. Anal. Chem. Int. 76 (1993) 92-94.

[12] Capolongo F., Baggio A., Piro R., Schivo A., Mutinelli F., Sabatini A.G., Colombo F., Marcazzan G.L., Massi S., Nanetti A., Trattamento della varroasi con acido formico: accumulo nel miele e influenza sulle sue caratteristiche, L'Ape nostra amica 8 (1996) 4-11.

[13] Darchen R., La cire, son recyclage et son rôle probable à l'intérieur d'une colonie d'Apis mellifica, Apidologie 11 (1980) 193-202.

[14] De Greef M., De Wael L., Van Laere O., Bestimmung der Rückstände von Fluvalinat in belgischem Honig und Bienenwachs, Allg. Dtsch. Imkerztg. 7 (1994) 7-8.

[15] De Lahitte J.D., A propos du Perizin, Santé de l'Abeille 98 (1987) 54-61.

116] De Paoli M., Taccheo B.M., Solid-phase extraction and gas chromatographic determination of flumethrin residues in honey, Pestic. Sci. 34 (1992) 61-63.

[17] Faucon J.P., Flamini C., Traitement de la varroatose. Étude comparative de dispositifs à libération lente : essais préliminaires, Bulletin des GTV 1 (1989) 49-52. 
[18] Fernández Muino M.A., Simal Lozano J., Gas chromatographic-mass spectrometric method for the simultaneous determination of amitraz, bromopropylate, coumaphos, cymiazole and fluvalinate residues in honey, Analyst 118 (1993) 1519-1522.

[19] Floris I., Papoff C.M., Prota R., Controllo autunnale con Apitol di Varroa jacobsomi Oud. in un ambiente mediterraneo, Apicoltura 10 (1995) 33-42.

[20] Fries I., Wallner K., Rosenkranz P., Effects on Varroa jacobsoni from acaricides in beeswax, J. Apic. Res. 37 (1998) 85-90.

[21] Garcia M.A.F., Melgar M.J.R., Latorre C.H., Fernandez M.I.G., Evidence for safety of coumaphos, diazinon and malathion, Vet. Hum. Toxicol. 36 ( 1994 ) 429-432.

[22] Gufler H.K., Wallner K., Apistanresistente Varroamilben auch in Südtirol. Bienenwelt 37 (1995) $165-166$.

1231 Hansen H., Petersen J.H., Residues in honey and wax after treatment of bee colonies with bromopropylate, Dan. J. Plant Soil Sci. 92 (1988) $1-6$.

[24] Imdorf A., Charrrière J.D., Altemative Varroabckämpfung, Eidgenössische Forschungsanstalt für Milchwirtschaft, Bern, 1998.

[25] Imdorf A., Bogdanov S., Kilchenmann V.. Maquelin C., Apilife VAR: a new varroacide with thymol as the main ingredient, Bee World 76 (1995) 77-83.

126] Jiménez J., Atienza J., Bernal J.L., Characterization of fluvalinate residues in honey by gas chromatography, J. High Resol. Chromatogr. 18 (1995) 367-372.

[27] Jiménez J., Bernal J.L., del Nozal M.J., Toribio L., Characterisation and monitoring of Amitraz degradation products in honey, J. High Resol. Chromatogr. 64 (1997) 81-84.

[28] Klein E., Rückstände des Akarizids Chlordimcform in Honig, Lebensm. Gerichtl. Chem. 43 (1989) 86-93.

[29] Klcin E., Weber E., Hurler E., Mayer L., Gaschromatographische Bestimmung von Isopropyl-4.4-Dibrombenzilat (Brompropylat), 4.4-Dibrombenzophenon und verschiedenen Akariziden in Honig und Wabenwachs, Dtsch. Lebensm. Rundsch. 82 (1986) 185-188.

[30] Kubik M., Nowacki J.. Michalczuk L., Pidek A.. Marcinkowski J., Penetration of fluvalinate into bee-products, J. Fruit Ornam. Plant Res. 1 (1995) 13-22.

131] Laub E., Metzler B., Putz A., Roth M., Zur Rückstandssituation zugelassener Varroatosebekämpfungsmittel in Honig. Lebensm. Gerichtl. Chem. 4 (1987) 107-109.

[32] Liebig G., Varroaleitfaden, Landesverband Württembergischer Imker, Stuttgart, 1990.

[33] Liebig G., Einfach Imkern, Gerhard Liebig, Stuttgart, 1998.
[34] Lodesani M., Pellacani A., Bergomi S., Carpana E., Rabitti T., Lasagni P., Residue determination for some products used against Varroa infestation in bees, Apidologie 23 (1992) 257-272.

135| Lubinevski Y., Stern Y., Slazbezki Y., Lensky Y., Ben-Yossef H., Gerson U., Control of Varroa jacobsomi and Tropilaelaps clareae mites using Mavrik in Apis mellifera colonies und subtropical and tropical climates, Am. Bee J. 128 (1988) 48-52.

[36] Marx H., Stolle A., Zum gesundheitlichen Risiko für den Honigkonsumenten bei Behandlung eines Befalles mit Varroamilben mittels Oxalsäure, Amtsticrärztl. Dienst Lebensmitt.kontr. 4 (1997) 164-165.

137] Milani N., The resistance of Varroa jacobsoni Oud to pyrethroids: a laboratory assay, Apidologie 26 (1995) 415-429.

[38] Moosbeckhofer R., Ergebnisse aus Biotests über die Langzeitwirkung von Apistan und Bayvarol, Bienenwelt 33 (1991) 149-154 and 179-181.

139] Mutinelli F., Baggio A., Capolongo F., Piro R., Prandin L., Biaison L., A scientific note on oxalic acid by topical application for the control of varroosis, Apidologie 28 (1997) 461-462.

140] Pechhacker H., Wallner K., Zur Rückstandsfrage im Rahmen der Varroabehandlung, Bienenvater 111 ( 1991 ) 46-48.

141| Piro R., European legislation for residues in bee products, in: 25th Int. Apicultural Congress, Antwerpen 1997, Apimondia Publ. House, Bucharest, 1999 (in press).

142] Sherma J., McGinnis S.C., Determination of pentachlorphenol and cymiazole in water and honey by $\mathrm{C}-18$ solid phase extraction and quantitative HPTLC, J. Liq. Chromatogr. 18 (1995) 755-761.

[43] Slabezki Y., Gal H., Lensky Y.. The effect of fluvalinate applications in bee colonies on populations levels of Varroa jacobsoni and honey bees (Apis mellifera $\mathrm{L}$.) and on residues in honey and wax, BeeScience 1 (1991) 189-195.

[44] Stehr C., Wachendörfer G., Seeger H., Gaschromatographische Rückstandsuntersuchungen auf Brompropylat bei Honig, Wachs und Propolis nach Anwendung von Folbex VA Neu im Rahmen der Varroatosebekämpfung, Tierärztl. Umsch. 51 (1996) 249-254.

[45] Stoya W., Wachendörfer G., Kary I., Siebentritt P., Kaiser E., Ameisensäure als Therapeutikum gegen Varroatose und ihre Auswirkungen auf den Honig, Dtsch. Lebensm. Rundsch. 82 (1986) 217-221.

[46] Stoya W., Wachendörfer G., Kary I., Siebentritt P., Kaiser E, Milchsäure als Therapeutikum gegen Varroatose und ihre Auswirkungen auf den Honig, Dtsch. Lebensm. Rundsch. 83 (1987) $283-286$. 
[47] Stricker O., Gierschner K., Vorwohl G., Gaschromatographische Bestimmung von Brompropylat, 4,4-Dibrombenzophenon, Coumaphos und Fluvalinat in Honig, Dtsch. Lebensm. Rundsch. 3 (1989) 72-75.

[48] Taccheo M., De Paoli M., Spessotto C., Determination of total amitraz residues in honey by electron capture capillary gas chromatography A simplified method, Pestic. Sci. 23 (1988) 59-64.

[49] Taccheo M., De Paoli M., Spessotto C., The determination of coumaphos residues in honey by HPTLC with in-situ Fluorimetry, Pestic. Sci. 25 (1989) 11-15.

[50] Thrasyvoulou A.T., Pappas N., Contamination of honey and wax with malathion and coumaphos used against the varroa mite, J. Apic. Res. 27 (1988) 55-61.

[5]] Trouiller J., Monitoring Varroa jacobsoni resistance to pyrethroids in western Europe, Apidologie 29 (1998) 537-546.

[52] Van Buren N.W.M., Marien A.G.H., Velthuis H.H.W., The role of trophallaxis in the distribution of Perizin in a honeybee colony with regard to the control of the varroa mite, Entomol. Exp. Appl. 65 (1992) 157-164.

[53| Van Buren N.W.M., Marien A.G.H., Velthuis H.H.W., Oudejans R.C.H.M., Residues in beeswax and honey of Perizin, an acaricide to combat the mite Varroa jacobsoni Oudemans, Environ. Entomol. 21 (1992) 860-865.

[54] Van Rillaer W., Bernaert H., Determination of residual bromopropylate and coumaphos in honey and honey comb by capillary gas chromatography, Z. Lebensm. Unters. Forsch. 188 (1989) 135-137.

[55] Vesely V., Malonova H., Titera D., Acrinathrin, an effective varroacide and its residues in stores, honey and wax, Apidologie 26 (1988) 321-322.

[56] Vesely V., Machova M., Hessler J., Hostomska V., Lenicek $\boldsymbol{J}$., Reduction of fluvalinate in beeswax by chemical means, J. Apic. Res. 33 (1994) 185-187.

[57] Wachendörfer G., Keding H., Beurteilung von Rückständen im Honig aus der Sicht der amtlichen Lebensmittelüberwachung nach Anwendung von Varroatose-Bekämpfungsmitteln, Allg. Dtsch. Imkerztg. (1988) 414-421.

[58] Wallner K., Diffusion varroazider Wirkstoffe aus dem Wachs in den Honig. Apidologie 23 (1992) 4.

[59] Wallner K., Varroabekämpfungsmittel - Eine Gefahr für den Honig, Die Biene 2 (1992) 61-67.

[60] Wallner K., Apitol-Zulassung - zwischen den Zeilen gelesen. Allg. Dtsch. Imkerztg. 1 (1992) 14-15.

[61] Wallner K., A method for determination of varroacide residues in bees wax, Apidologic 24 (1993) 502-503.

[62] Wallner K., Bienenschäden im Weinbau, Dr. Nienhaus Verlag, Stuttgart, 1994.

[63] Wallner K., The use of varroacides and their influence on the quality of bee products, Am. Bee J. 12 (1995) 817-821.

[64] Wallner K., The actual beeswax quality in foundations on the market, Apidologie 28 (1997) 168-170.

[65] Wallner K., Der Weg zur rückstandsfreien Imkerei - Strategien aus der Sackgasse, Bienenvater 118 (1997) 9-12.

[66] Wallner K., Kerzen aus Bienenwachs - ein Risiko, Schweiz. Bienenztg. 121 (1998) 760-764.

[67] Wallner K, Luh M., Womastek R., Pechhacker H., Moosbeckhofer R., Entwicklung der Rückstandssituation am Institut für Bienenkunde seit Beginn der Varroabehandlung, Bienenvater 116 (1995) 320-329.

[68] Zimmermann S., Gierschner K.H., Vorwohl G., Bestimmung von Brompropylat, 4.4-Dibrombenzophenon, Coumaphos und Fluvalinat in Bienenwachs, Dtsch. Lebensm.-Rundsch. 11 (1993) 341-344. 